\title{
Article
}

\section{The challenge of managing informally}

Saundry, Richard Arthur, Jones, Carol and Wibberley, Gemma

Available at http://clok.uclan.ac.uk/12373/

Saundry, Richard Arthur, Jones, Carol and Wibberley, Gemma ORCID: 00000002-7827-8227 (2015) The challenge of managing informally. Employee Relations, 37 (4). pp. 428-441. ISSN 0142-5455

It is advisable to refer to the publisher's version if you intend to cite from the work. http://dx.doi.org/10.1108/ER-06-2014-0061

For more information about UCLan's research in this area go to http://www.uclan.ac.uk/researchgroups/ and search for < name of research Group>.

For information about Research generally at UCLan please go to http://www.uclan.ac.uk/research/

All outputs in CLoK are protected by Intellectual Property Rights law, including Copyright law. Copyright, IPR and Moral Rights for the works on this site are retained by the individual authors and/or other copyright owners. Terms and conditions for use of this material are defined in the policies page.

\section{CLoK}

Central Lancashire online Knowledge www.clok.uclan.ac.uk






\section{Structured Abstract:}

Purpose: This paper explores the orientations of line managers in handling workplace conflict. In particular it examines the tension between the traditional preference of frontline managers for informal approaches and the perceived certainty of written disputes procedures.

Design: The paper draws upon findings from 12 organisational case-studies, focussing on interviews conducted with HR and managers.

Findings: As line managers undertake more responsibility for people management, their preferences for informal approaches to workplace issues appears to be being replaced by a more rigid adherence to policy and procedure. This is largely driven by a lack of confidence and expertise in conflict management and a fear of the repercussions (both legal and organisational) of mishandling difficult issues. Written procedure therefore provides managers with both a systematic guide but also a protective shield against criticism and litigation.

Research limitations: It is not possible to generalise from a limited sample, therefore this suggested change requires further exploration to assess whether it has been evidenced in organisations more widely.

Practical implications: For practitioners this research highlights the critical requirement for organisations to develop key skills among line managers to enable them to respond effectively to problems at an early stage.

Social implications: For policy-makers, the barriers to line managers implementing informal resolution should be considered.

Originality/value: This article enriches understanding of line managers' current role in people management and the challenges they face in doing so informally. 


\section{The Challenge of Managing Informally}

\section{Introduction}

Since the publication of the Gibbons Review into the UK's system of dispute resolution (2007), public policy has signaled a loosening of regulation and the promotion of more informal approaches to resolving workplace issues. The abolition of statutory dismissals and grievance procedures in 2008 and the introduction of a less prescriptive Acas Code of Practice on Disciplinary and Grievance Procedures was followed by the Coalition's consultation over 'Resolving Workplace Disputes' which set out their vision "for an employment dispute resolution system that promotes the use of early dispute resolution as a means of dealing with workplace problems" (BIS, 2011a, p.3). The Government argued that the existing regulatory framework encouraged unduly formal approaches to workplace disputes which increased costs and restricted economic growth (BIS, 2011b). Subsequently, a series of measures has been introduced aimed at curbing the risks of employment litigation and providing employers with greater flexibility in the way that they respond to individual employment disputes.

Whether organisations and line managers are prepared or equipped to use this discretion is an important question. Certainly, the Government doubts the ability of line managers to resolve disputes informally: "it is clear that many more problems could be prevented from escalating into disputes if line managers were better able to manage conflict" (BIS, 2011a, p.17). Critically, despite the continued shift of responsibility for conflict management from HR to the line (McGovern et al., 1997; Teague and Roche, 2012), this concern has received little further consideration as the policy agenda has developed. Furthermore, it could be argued that the traditional preference of managers for informality (Rollinson et al., 1996) may sit uneasily beside increased emphasis on more systematic performance management (Taylor, et al., 2010; Newsome et al., 2013).

The paper draws upon findings from 12 organisational case studies, conducted in two waves. The first wave focussed on disciplinary and grievance procedures, whilst the second explored companies' methods for managing workplace conflict. The data from these studies demonstrates that managing conflict 'informally' is both complex and challenging for managers and suggests that the 'informal ideal' may sit uncomfortably with organisational requirements regarding consistency, and line managers own concerns about their responsibilities in relation to the process. In fact, we argue that these pressures are likely to result in more procedural approaches being favoured.

The evidence from the case studies highlights there are multiple, interrelated and conflicting reasons for this shift in managers' preferences towards formal dispute handling including increased use of performance management systems; fear of the potential repercussions from mishandled informal resolution; the continued influence of procedures; and the increasing trend to standardise 'informal' methods to ensure consistency.

We begin the article by discussing existing research into line managers' preferences and abilities in handling workplace problems. The methods used in this research are then set out and the findings are presented. Finally, the discussion and conclusion examine the conceptual and policy implications.

\section{Literature Review}


As part of an on-going devolution of people management responsibilities, the role of line managers (McGovern et al., 1997; Cunningham and Hyman, 1999; Hall and Torrington, 1998b; Larsen and Brewster, 2003) has progressively shifted to what Hales describes as 'performance oriented supervision' (Hales, 2005). This includes appraisal and performance review practices as part of a developmental approach, but also involves the management of poor performance (Dunn and Wilkinson, 2002; Newsome et al., 2013) through the application of absence and capability procedures. Although these are also now more explicitly linked to disciplinary outcomes, managers are encouraged to act in a 'flexible and positive way' (Armstrong and Barron 2005, p.12) and there appears to be an emphasis on the benefits of informality as a way of building consensus and enhancing performance in the context of employee involvement for example (Marchington and Suter, 2013). 'Proactive' interventions by line managers are increasingly perceived to reduce the likelihood of problems becoming entrenched or escalating into more overt conflict between the individual employee and the organisation, thus avoiding formal disciplinary sanctions (Teague and Roche, 2012).

Managers are known to value having a degree of discretion in exactly how and when routine performance management intersects with formal procedures leading to disciplinary outcomes (Hunter and Renwick, 2009, p.407). Indeed for many line managers the rigid application of formal procedures does not support the swift and flexible response that is often required in dealing with day-to-day issues (Townsend et al., 2012: 344). Thus, existing relationships with employees and operational considerations often play key roles in how a manager assesses the response to a particular situation. They can be reluctant to take action that could lead to them losing key personnel even if this subverts rules within the wider workplace (Edwards and Whitson, 1989; Dunn and Wilkinson, 2002; Cole, 2008). They are also noted to be reluctant to delve into what they see as personal issues and to manage performance more generally (Edwards, 2005, p.393; Hutchinson and Purcell, 2003). Evidence from research on employee involvement suggests that employees also favour informal approaches but as Marchington and Suter comment (2013: 305), this is unlikely to be the case in relation to discipline and grievance issues where the formality of the procedure provides a degree of 'safety' for all parties.

As organisations face increased pressure to reduce costs and increase efficiency, problems regarding absence and capability are less likely to be tolerated (Taylor et al., 2010; Traynor et al., 2014). This may also create an environment in which informal approaches to conflict resolution are difficult to sustain. Front-line managers may be expected to manage these issues robustly and the application of procedure may more visible to senior managers than informal dialogue. Furthermore, informality can result in inconsistencies in how employees are treated, which can damage employee morale, satisfaction and trust (Rosen and Jerdee, 1974 and Arvey et al., 1982 both cited in Cole, 2008, p.110) and which could have serious consequences in any legal dispute (Rollinson et al., 1996, p.53; Earnshaw et al., 2000).

Importantly, the approach taken by managers to conflict may also be affected by their competence and confidence in dealing with such issues (CIPD, 2007; Hutchinson and Purcell, 2010; Jones and Saundry, 2012). Unsurprisingly the CIPD highlight that 'conflict management' and 'managing difficult conversations' are the two most challenging parts of a line manager's role (CIPD, 2013, p.7). However, managers are rarely trained specifically in conflict management (Teague and Roche, 2012) or in the complex skills associated with managing poor performance effectively (Saundry and Wibberley, 2014). Nor are they typically recruited based on their people management skills (Townsend, 2013). Furthermore, 
line managers are unlikely to receive support from senior management (Hales, 2005). Dealing with people management issues is typically seen as a lower priority than meeting organisational targets (Renwick, 2003) and the perception that this is also time consuming further shapes responses (Guest and King, 2004). Their dual role of managing staff and operations is exacerbated as workloads intensify, causing levels of conflict to rise, but resources to manage this to simultaneously fall (Hyde et al., 2013).

As alluded to earlier, many front-line managers are caught between what Harris et al (2002, p.616) describe as the 'paradox' of trying to balance formal and informal aspects to processes and procedures. They are simultaneously expected to act as interpreter of a policy which stresses a formalised and standardised approach, senior managers' expectations that they will act proactively to spot and address problems before they escalate, and to coach and mentor employees whilst also maintaining positive working relationships that continue to engender a committed and productive ethos (Townsend, 2013; Marchington and Suter, 2013; Wilkinson, Townsend and Burgess, 2013; Townsend et al., 2012). As research on employee involvement has shown (Townsend, 2013; Marchington and Suter, 2013; Wilkinson et al., 2013; Townsend et al., 2012), the boundaries between formal and informal elements of managerial action can often be quite blurred. However, in relation to discipline this blurring is particularly problematic since defining when poor performance actually occurs is neither easy nor clear, making it difficult to know precisely when a formal procedure should be enacted (Goodhew et al., 2007, p.959; Hamilton 2007 cited in Traynor et al., 2014,p.55). Perhaps in recognition of this, Cooke (2006, p.698) also suggests, that managers can hide behind the formal procedure to justify a decision to discipline an employee and may move to formal sanctions very quickly. Furthermore, managers may not relish having more discretion in managing conflict (Harris et al., 2002, p.225), particularly if the impact of making the 'wrong' decision would have negative consequences for them.

Superficial contempt for formal procedure may thus mask a lack of confidence on the part of managers in dealing with difficult issues, and may lead to an over-reliance on HR practitioners. However, HR professionals generally provide an arm's length advisory service leaving the line or operational manager directly responsibility for handling difficult issues (Hall and Torrington, 1998a, 1998b; Huws and Podro, 2012). This remote HR can pose challenges for managers requiring more support in handling cases (Whittaker and Marchington, 2003; Keegan et al., 2011). This may be exacerbated by a fear of the legal ramifications and/or internal scrutiny if managers are seen to have mishandled a situation (Latreille, 2011), leading line managers to adopt formal, less 'risky' approaches to handling disputes (Jones and Saundry, 2012).

This discussion is not just of conceptual significance but has clear implications for policy and practice. The post-Gibbons policy agenda has refocused attention on the 'positive' dimensions of informal processes for dispute resolution. However, the HR community appears to be sceptical about the ability of line managers to make effective use of greater flexibility (CIPD, 2007; 2008). Yet, neither the Gibbons (2007) review nor the government's subsequent response discussed in any detail the role played by managers.

We aim to fill this gap by highlighting managers' approaches for handling workplace conflict, and the challenges they face in doing so informally. We do this by asking the following questions: what role do managers take in managing workplace problems? How do they operationalize that role? What organisational policies and processes are in place for 
people management? What barriers and enablers do managers' face in addressing workplace disputes?

\section{Methodology}

This paper draws on data from a variety of discrete projects, carried out over two waves. The first wave was primarily designed to examine accompaniment and representation in disciplinary cases and employee grievances. This involved case studies at seven different sites. This was then followed by five case studies which examined specific aspects of conflict management. Although the two waves of research were separate, a common area of enquiry in both projects and the semi-structured interviews conducted within them was the role played by front-line managers in handling workplace conflict.

While each of the studies was undertaken as a stand-alone project the methods used and the research questions focussing on the management of workplace conflict were broadly similar, allowing cross comparisons. The use of multiple case-study sites reflected the need for a methodological approach that exposes the social processes that shape workplace conflict (Dickens et al., 2005). Cases were selected to encompass different organisational types in terms of industrial activity, sector, size and nature of employee representation. Broad details are contained for all cases in the tables below, although specific features are not identified in order to preserve anonymity.

\section{Insert Table 1 here}

Within each organisation, research consisted of two main elements: examination of policy documentation for dealing with individual employment disputes; in-depth interviews with key informants including HR practitioners, operational managers and employee representatives and/or employees who had acted as companions. Interviews were split between the authors, following a pre-agreed topic guide. In wave one; further interviews were conducted with regional officers of trade unions that covered those workplaces without lay union representatives. In wave two, research also included exploration of available statistical data regarding the workforce and employment disputes.

Across the whole sample, 157 interviews were carried out. Wave one was conducted in 2008. It consisted of 26 interviews with eight HR managers, nine operational managers and nine trade union representatives and companions. Interviews lasted between 45 and 75 minutes.

The second wave was conducted between 2010 and 2012. These case studies were more detailed. 131 interviews were conducted, comprising 104 hours of interview data. In broad terms the sample across the five cases could be broken down as follows: 53 HR practitioners ranging from HR adviser to HR director level; 66 line and operational managers; and 17 employee representatives from trade unions or staff associations.

Importantly, the case-studies were not focussed on how individual cases were conducted but on the formal and informal processes that constitute the management of conflict within the organisation. Accordingly, interviews were neither sought nor conducted with individual employees who were involved with employment disputes. Furthermore, while the detail and the number of interviews in each case varied, the emphasis in this paper is to examine the views of respondents across the sample as a whole rather than on the way in which specific organisational contexts can shape the way in which conflict is managed. 
Across the case studies membership of either trade unions and/or staff associations was relatively high in many of the organisations; therefore, we would suggest that the views of employee representatives interviewed would provide an indication of the broad views of employees within those organisations.

This paper focuses on the interview data, which was initially analysed to provide an overview of the line managers' approaches to handling conflict. A process of open coding was then used to break down, conceptualize, and compare the interview texts (Strauss and Corbin,

1998). Subsequently, further themes and subthemes were identified, and interview transcripts were explored and compared to provide further insights into the nature of workplace conflict management, the tensions between informal and formal dispute resolution, and line managers' changing role within this.

\section{Findings}

\section{The challenges of managing informally}

In all the organisations that we examined, line managers either had taken, or were taking, much greater responsibility for the day-to-day management of performance, conflict, disciplinary action and employee grievances (Teague and Roche, 2012). A typical comment was that 'managers should manage', with one HR manager adding "...line managers are owners of the process. They are responsible for managing people, not HR" (Organisation 1). Simultaneously, there was a general agreement that trying to resolve issues at the earliest stage and avoiding formal procedures was desirable. Consequently, informal discussion and counselling were encouraged before formal disciplinary procedures were invoked:

What we always encourage, is informal chats and counselling before we get into the disciplinary procedure...we wouldn't dive straight into the disciplinary procedure. We'd either expect the team leader to have a quiet chat with someone, say, "Hey, do you realise what you're doing?"... "Look, you need to pull your socks up",... and if no improvement is seen say, "Look, I'm going to have to counsel you" (Manager - Organisation 1)

However, applying an informal approach in practice presented many challenges, particularly for more junior, front-line managers. For example, it was argued that managers needed a degree of "foresight to be able to recognise that there's an issue before it needs to be confirmed" (HR practitioner - Organisation 1). This required skills that could only be acquired through direct experience. While process and procedure could be learned through training, there was a sense that informal resolution required a sensitivity to the way in which conflict could escalate that could only be learned by doing and, in some cases, failing:

Although we've got [the HR manager] there, if you become a manager all of a sudden you've got staff,...It's great reading the book, but you can say the wrong things, and you can sometimes get yourself into hot water before you actually realise. So I think it's only through experience... you learn as you go along. (Manager - Organisation 4).

\section{Performance management - facilitating informal resolution?}

In this context, it might be suggested that formal performance management mechanisms could provide a clear structure and framework that less experienced managers were able to follow. For example, there was evidence that the effective operation of appraisal systems 
could have a beneficial impact. In one organisation, all staff had regular one-to-one meetings with their line managers which were logged, to discuss their key performance indicators (KPIs). Metrics of this type could help to bring potential problems out into the open and provide managers an opportunity to discuss issues at an early stage and resolve them informally:

It's an indicative tool to suggest where there may be any process issues or people problems...we would be having a two way discussion with the manager about their department's performance. (Manager - Organisation B)

In Organisation B, both management and union respondents saw this as not only maintaining important channels of communication but providing a place in which employees and managers could raise and try to resolve concerns, at an early stage, rather than ignoring problems. In this way formal and informal aspects of conflict resolution were closely intertwined (see for example Townsend, 2013).

However, across the sample as a whole, the way in which formal systems for addressing poor performance interacted with more informal approaches was often complex and could be problematic. For some managers, such systems were seen as simply adding to high workloads and severe pressures to meet operational objectives and targets (Hyde et al., 2013). As a result, there was a danger that informal communication could be squeezed out and more formalised performance management seen as a 'chore'. In such cases, there was a danger that employee appraisals were reduced to 'box ticking' exercises and as a result, warning signs of potentially serious problems could be missed or simply ignored:

I think one our biggest faults of performance management is that it comes to the end of year review and then people are then just told that they're not good enough but there's been nothing through the year, there's been no sort of coaching (HR practitioner - Organisation D)

This also reflects a concern, particular expressed by HR respondents that front-line managers sometimes saw more formal processes as a means of justifying or legitimising arbitrary action rather than encouraging them to seek to resolve the issue at an early stage (see Cooke, 2006; Earnshaw et al 2000). An HR practitioner explained this as follows:

Managers are actually getting better but sort of, at first it was a case of "this person is rubbish. I want them out of the door". "Well, what training have you given them?" And it's just really sort of making people aware that you need to throw more training at them. You need to sit with them. (Organisation 4)

Again, this emphasises the importance of learning-by-doing and the developmental role of HR practitioners. At the same time it exposes tensions between different conceptions of formality - for HR practitioners, performance management processes provided a framework within which resolution could be sought, while for line managers, they were something to be avoided or applied in a rigid manner.

\section{Contingency and consistency}

From the perspective of HR practitioners, an additional benefit of formalised processes was that they provided a degree of consistency which not only encouraged fairness and equity but also underpinned legal compliance. In contrast, managers argued that in order to resolve conflict proactively and constructively, they needed both the confidence and the flexibility to 
use their own, inevitably subjective, judgement (see also Townsend et al., 2012). According to one front-line manager:

If someone's grandma has died and they've had a day off for the funeral, yes, that policy may state it's an absence and that policy will state a disciplinary but hang on a minute, you've got to have compassion. You've got to care about that person and you've got to ask yourself the question, would it be fair if you were sent to a disciplinary for that reason? (Organisation 3).

Furthermore, each individual case tended to be different and complex. As a senior operational manager explained:

You can go on all the courses and do a bit of role play but nothing can face you for a disciplinary hearing". The times I've gone in there thinking, oh this is bang to rights when I was a supervisor and they throw something at you and you think I never expected that. So it definitely does depend on experience (Organisation 1).

In this way, although HR practitioners encouraged informal responses to conflict, their insistence on consistency as expressed through process and procedure could inhibit the contingency that line managers felt was necessary to develop nuanced resolutions. Moreover, it was clear that while experienced and more senior managers had the confidence to step out of, or 'bend' procedure if necessary, managers who were new to the role, younger and who lacked experience found it much more challenging:

When you're experienced, you,...take risks...you're more likely to have that conversation...whereas for example...if you're younger and, and coming into a new system...you tend to stick very rigidly [to the procedure], because you're almost afraid (Senior manager - Organisation D)

\section{The risks of informality}

Therefore, using informal channels to manage performance and handle disciplinary and grievance issues was seen as risky for a number of reasons. First, addressing conflict could impact on established working relationships (Cole, 2008). Second, it could lead to litigation. Indeed, some respondents suggested that the negative perception of the implications of a claim to the employment tribunal was a key factor in dissuading managers from taking an informal approach:

Every manager in this organisation will know of a grievance that went horribly wrong and that ended up in say an employment tribunal and things and there's a lot of fear about if they dabble in some sort of informal they might get it wrong and then the complaint will turn against them. (Mediator - Organisation C)

Third, there was a palpable fear expressed by more junior managers within the sample that operating out of procedure could result in internal criticism both from senior managers and also HR practitioners (Latreille, 2011):

Our managers are initially worried about... the embarrassment of not dealing with things properly and secondly, the internal procedures...if something goes through to an appeal situation,... if it hasn't been properly dealt with at managerial level then they'll be criticised. (HR practitioner - Organisation 6). 
Therefore, the findings exposed a key contradiction; while there was a demand from HR practitioners and senior management for managers to address and resolve issues at an early stage, the environment within many of our case-study organisations had not been created which facilitated this.

\section{The power of procedure}

This was also reflected in the way in which managers and HR practitioners articulated the role of procedure in informing and shaping responses to conflict. In fact, contrary to the evolution of the policy discourse, our findings suggest that procedures were becoming more potent as organisations sought to increase efficiency and cut costs (see for example Taylor et al., 2010).

Pressure from senior management to 'sort out issues' and meet performance targets could push more junior front-line managers to eschew informal routes to resolution in favour of rigid but more visible formal action. A number of respondents pointed out that a desire to be seen to reduce absence levels, in line with revised organisational policy, had made it more difficult to adopt nuanced and informal resolutions that took into account the circumstances of each case:

We've tightened up our internal application of the policy within management of long-term absence...I think that before we ignored it so it was very rare to take somebody down a disciplinary... now... we're applying the actual policy. (Manager - Organisation B)

Front-line managers felt that they were often placed in an invidious position as they were asked to implement policy and process but then criticised for applying it too rigidly. A stark illustration of this was an organisation which had introduced a rule whereby swearing was deemed to be gross misconduct. The original rationale had been to avoid customers overhearing bad language but managers had initially treated all examples of foul language as reason for summary dismissal. This approach was modified as HR practitioners felt that there was a need for a more subtle and contingent approach. Similar tensions were replicated across the study:

The number of times when that conversation [between the manager and the employee] could have happened and didn't and the first time it happens is when there's been a repeat of the issue several times and it then becomes a serious issue that's got to be dealt with in process. There's no going back then, but the individual could have been corrected at an earlier stage and when I ask managers why they didn't do that, it's "We'll we've got a procedure, we'll follow the procedure" and I've said, "No, you didn't need to do that. You could have talked to them earlier". It's like they use the procedure as a backdrop for doing everything. (HR practitioner - Organisation 1).

Respondents also alleged that some front-line managers would simply trigger formal processes hoping that this would then be 'someone else's problem'. There was a feeling that for many line managers handling disputes informally was too time consuming, too challenging and too distracting from their operational role. Therefore activating a formal procedure was seen as the easier option:

Sometimes it's just lack of time, people... take the easy way out, they make a decision without any thought to it...Because it's written down and that is the policy'(Manager Organisation D) 


\section{Formalising the informal}

Therefore, although the devolution of responsibility would appear to place greater power in the hands of front-line managers, our findings suggest that the discretion that they enjoy is constrained both by the exercise of policy, the threat of criticism and the potential for litigation. Critically, HR practitioners in the sample retained significant influence as 'guardians' of the organisational record and protectors of 'consistency'. One senior manager explained that:

I would always say [to my HR reps],"I need to understand whether this is a consistent approach. So I don't want to set a precedent today that's going to screw my colleague up for something he did last week". (Organisation 1).

It was noted by several front-line managers that HR representatives, particularly where they also were inexperienced, could act as a brake on adopting more informal approaches:

The HR advice we get will almost 100 per cent err on the side of having formal investigations... [but] in this sector... everything's grey...Quite often it is about judgement and you do need to be aware of the individual's background and previous performance (Front-line manager - Organisation E)

This was not universal, however, and the evidence suggested that where there were close and trusting relationships between HR practitioners and managers were able to work together to address and resolve issues at an early stage, minimising the need for formal procedure. This was particularly the case in organisations with on-site HR practitioners (Saundry and Wibberley, 2014).

Nonetheless, there remained a tension between the preference of many managers to respond to performance and conflict issues in a flexible way that reflected operational priorities, and the focus of HR on fairness and consistency. This tension was in some ways crystallised in in the formalisation of informal processes. This could range from HR practitioners emphasising that any 'discussions' between a manager and an employee over performance or disciplinary matters were recorded to the introduction of 'improvement notes':

Part of the informal performance management tool is something that we call an improvement note, [Managers] might do like a mini investigation, get to the bottom of something and then issue an improvement note for minor misconduct, lateness and things like that. So we've said to all team managers, if we end up giving a warning for lateness we want to have seen an improvement note first, (HR practitioner - Organisation D)

Thus there was clear evidence that organisations were increasingly 'formalising' and to some extent standardising, the informal, as this manager acknowledged:

Whilst we can have an informal approach it has to be a fairly broadly understood informal approach because again you can cause problems by having someone dealing with the informal elements one way and someone dealing with the informal elements a different way... within the discipline and grievance procedure...there are mechanisms in there where we highlight issues beforehand, call people in and say, look this is evident from your attendance...can we sort this out?...And that's an informal approach to it before we go to any sort of formal, and we're trying to standardize that. (Manager - Organisation 6) 


\section{Discussion and conclusions}

It could be argued that the current government emphasis on the informal resolution of disputes and conflict in the workplace (Gibbons, 2007; BIS 2011a, b) fits well with managers' own preferences. However, our case studies suggest that managing informally is both complex and challenging and that for various reasons both organisations and managers might find procedural approaches to be more straightforward.

Changes in the structure of the HR function have left line managers responsible for conflict management and dispute resolution (Teague and Roche, 2012). This is not only problematic given the concerns over managerial capability (CIPD, 2007), but accentuated by factors which we found were encouraging risk averse and formalised responses to conflict.

Traditionally, it has been argued line managers prefer to handle workplace disputes informally (Earnshaw et al., 2000), whilst HR practitioners prefer a more procedural approach to resolution (Cooke, 2006). However, this paper suggests that as conflict management has devolved to the line, front-line managers appear to have become more rigid in their adherence to procedure.

One issue is that less experienced managers often found dealing with conflict challenging and therefore preferred to rely on formal procedures. To some extent, our research reinforces the belief that the spectre of litigation shapes the behaviour of managers and the way that organisations address workplace conflict (Latreille, 2011). It deepens the sense of unease that many line managers feel in dealing with difficult issues and encourages an emphasis on legal compliance and the application of procedure. Furthermore, the potential threat of internal repercussions limited the extent to which managers addressed issues, or were prepared to take calculated risks in dealing with them informally.

Perhaps more importantly, line managers were being asked to take on the onus for dealing with conflict at the same time that pressures to reduce costs and increased efficiency were intensifying through the use of performance management systems (Taylor et al, 2010). Thus managers were expected to take formal action in cases that might have previously been ignored or handled informally.

It also appeared that policy still shaped managerial behaviour, providing a degree of security in the face of legal uncertainties and low levels of confidence. In this way, more formal processes could provide a degree of cover for managers (Cooke, 2006) and also the appearance of fairness and consistency (Cole, 2008). Moreover, the promotion of consistency in conflict handling had also resulted in the formalising of informal process.

Importantly, our findings suggest that despite the increasingly voluntaristic nature of the regulation of dispute resolution, front-line managers found themselves caught between demands for informal approaches to conflict and for robust management of performance and absence. These objectives were not necessarily contradictory - indeed, more experienced managers felt able to seek more nuanced resolutions, within the context of policy and procedure (Rollinson et al., 1996). However, this required a level of expertise and confidence that many managers did not appear to possess. 
For practitioners this research highlights the critical requirement for organisations to develop informal conflict management capacity among line managers. More fundamentally, we would argue that organisations need to recognise that conflict management is a strategic rather than a transactional issue and locate it within the core competencies of their managers and accordingly the criteria on which they are recruited, developed and appraised. Furthermore, the government's promotion of early dispute resolution is likely to have little effect unless policy addresses the challenges that line managers face in handling people management issues.

Of course, we must be cautious in drawing broad conclusions from the data which is drawn from two separate waves of case studies. The sample is not representative of UK workplaces with the bulk of the data drawn from larger organisations, with sophisticated HR functions and structures of employee representation. Thus it cannot be suggested that this reflects conflict management across the UK, rather the paper offers an insight into a potential shift in line managers' preference towards handling issues formally. This suggested change in behaviour requires further exploration to assess whether this shift has been evidence in organisations more widely. 


\section{References}

Armstrong, M. and Barron, A. (2005), Managing Performance: Performance Management in Action, London: CIPD,

BIS (2011a), Resolving Workplace Disputes: A Consultation, London: BIS.

BIS (2011b), Resolving Workplace Disputes: Government Response to the Consultation, London: BIS.

CIPD (2007), Managing Conflict at Work - Survey Report, London: CIPD.

CIPD (2008), Workplace mediation - how employers do it?, London: CIPD.

CIPD (2013), Real-life leaders: closing the knowing-doing gap, London: CIPD.

Cooke, H. (2006), "Examining the disciplinary process in nursing: a case study approach", Work, Employment and Society, Vol. 20, No.4, pp.687-707.

Cole, N. (2008), "Consistency in employee discipline: an empirical exploration", Personnel Review, Vol.37, No.5, pp.109-117.

Cunningham, I. and Hyman, J. (1999), "Devolving human resource responsibilities to the line: Beginning of the end or a new beginning for personnel?", Personnel Review, Vol. 28, No1-2, pp. 9027

Dickens, L., Hall, M. and Wood, S. (2005), Review of research into the impact of employment relations legislation, Employment Relations Research Series No. 45, London: DTI.

Dunn, C. and Wilkinson, A. (2002), "Wish you were here: managing absence", Personnel Review, Vol.31, No.2, pp. 228-246

Earnshaw, J., Marchington, M. and Goodman, J. (2000), "Unfair to whom? Discipline and dismissal in small establishments", Industrial Relations Journal, Vol.11, No.1, pp. $62-73$

Edwards, P. (2005), "The challenging but promising future of industrial relations", Industrial Relations Journal, Vol. 36, No.4, pp. 264-282.

Edwards, P. and Whitson, C. (1989), "Industrial discipline, the control of attendance and the subordination of labour: towards an integrated analysis", Work, Employment and Society, Vol. 3, No. 1, pp. 1-28

Gibbons, M. (2007), A review of employment dispute resolution in Great Britain, London: DTI.

Guest, D. and King, Z. (2004), "Power, innovation and problem-solving: The personnel managers' three steps to heaven?", Journal of Management Studies, Vol. 41, No.3, pp.401-423.

Hales, C. (2005), "Rooted in supervision, branching into management: continuity and change in the role of first-line manager", Journal of Management Studies, Vol. 42, No.3, pp.471-506.

Hall, L. and Torrington, D. (1998a), The Human Resource Function. The Dynamics of Change and Development, London: Pitman.

Hall, L. and Torrington, D. (1998b), "Letting go or holding on - the devolution of operational personnel activities", Human Resource Management Journal, Vol. 8, No.1, pp.41-55

Harris, L, Doughty, D., and Kirk, S. (2002), "The devolution of HR responsibilities perspectives from the UK's public sector", Journal of European Industrial Training, Vol. 26, No. 5, pp. 218-229

Hunter, W. and Renwick, D. (2009), "Involving British line managers in HRM in a small non-profit organisation", Employee Relations, Vol. 31, No. 4, pp. 398-411.

Hutchinson, S. and Purcell, J. (2003), Bringing Policies to Life - The Vital Role of Front Line Managers in People Management, London: CIPD. 
Hutchinson, S. and Purcell, J. (2010), "Managing ward managers for roles in HRM in the NHS: overworked and under-resourced", Human Resource Management Journal, Vol.20, No.4, pp. 357-374

Huws, U. and Podro, S. (2012), "Outsourcing and the fragmentation of employment relations: the challenges ahead", Acas Future of Workplace Relations discussion papers, Acas: London

Hyde, P., Granter, E., Hassard, J., McCann, L. and Morris, J. (2013), "Roles and Behaviours of Middle and Junior Managers: Managing New Organizational Forms of Healthcare. Final report, NIHR Service Delivery and Organization programme

Jones, C. and Saundry, R. (2012), "The Practice of Discipline: Evaluating the Roles and Relationship between Managers and HR Professionals", Human Resource Management Journal, Vol.22, No.3, pp.252-266

Keegan,A., Huemann, M. and Turner, R. (2011), "Beyond the line: exploring the HRM responsibilities of line managers, project managers and the HRM department in four project-oriented companies in the Netherlands, Austria, the UK and the USA", The International Journal of Human Resource Management, Vol. 23, No. 15, pp. 30853104

Larsen, H. and Brewster, C. (2003),"Line management responsibility for HRM: what is happening in Europe?", Employee Relations, Vol. 25, No. 3, pp. 228-244

Latreille, P.L. (2011), Workplace Mediation: A Thematic Review of the Acas/CIPD Evidence, Acas, $13 / 11$

Marchington, M. and Suter, J., (2013), "Where informality really matters: Patterns of Employee Involvement and Participation (EIP) in a non-union firm", Industrial Relations, Vol. 52, No. S1, pp 284-313.

McGovern, P., Gratton, L., Hope-Hailey, V., Stiles, P., and Truss, C. (1997), "Human resource management on the line?", Human Resource Management Journal, Vol.7, No.4, pp. 12-29

Newsome, K, Thompson, P. and Commander, J. (2013), '"You monitor performance at every hour': labour and the management of performance in the supermarket supply chain", New Technology, Work and Employment, Vol. 28, No. 1, pp. 1-15.

Renwick, D. (2003), "Line manager involvement in HRM: an inside view”, Employee Relations, Vol.25, No. 3, pp. 262-280.

Rollinson, D., Hook, C. and Foot, M. (1996), "Supervisor and manager styles in handling discipline and grievance. Part two - approaches to handling discipline and grievance", Personnel Review, Vol.25, No.4, pp. 38-55

Saundry, R. and Wibberley, G. (2014), Workplace Dispute Resolution and the Management of Individual Conflict -A Thematic Analysis of Five Case Studies, London: Acas, 06/14,

Strauss, A. and Corbin, J. (1998), Basics of qualitative research: Grounded theory procedures and techniques. London: Sage

Taylor, P, Cunningham, I., Newsome, K., and Scholarios, D. (2010), '"Too scared to go sick" - reforming the research agenda on sickness absence', Industrial Relations Journal, Vol. 41, No. 4, pp. 270-288.

Teague, P. and Roche, W. (2012), "Line managers and the management of workplace conflict: evidence from Ireland", Human Resource Management Journal, Vol.22, No.3, pp.235-251

Townsend, K. (2013), "To what extent do line managers play a role in modern industrial relations?", Asia Pacific Journal of Human Resources, Vol.51, No. 4, pp.421436 
Townsend, K., Wilkinson, A., and Burgess, J., (2012), "Filling the gaps: Patterns of formal and informal participation”, Economic and Industrial Democracy, Vol. 34, No. 2, pp 337-354.

Traynor, M., Stone, K., Cook, H., Gould, D., and Maben, J., (2014), "Disciplinary processes and the management of poor performance among UK nurses: bad apple or systematic failure?", Nursing Inquiry, Vol. 21, No. 1, pp. 51-58.

Whittaker, S. and Marchington, M. (2003), "Devolving HR responsibility to the line: Threat, opportunity or partnership?", Employee Relations, Vol. 25, No. 3, pp. 245 - 261

Wilkinson, A., Townsend, K., and Burgess, J., (2013), 'Reassessing employee involvement and participation: atrophy, reinvigoration and patchwork in Australian workplaces', Journal of Industrial Relations, Vol. 55, No. 4, pp. 583-600 
Table 1 : Case study organisations

\begin{tabular}{|c|c|c|c|c|c|c|}
\hline Wave & Organisation & Industry & Sector & Employment & \begin{tabular}{|c} 
Employee \\
Representation
\end{tabular} & Interviews \\
\hline \multirow{7}{*}{1} & 1 & Manufacturing & Private & Over 10,000 & $\begin{array}{l}\text { Unions } \\
\text { recognised }\end{array}$ & $\begin{array}{c}\text { HR manager } \\
\text { Ops. managers ( } 3) \\
\text { TU rep. }(2)\end{array}$ \\
\hline & 2 & Manufacturing & Private & Over 4, 000 & $\begin{array}{l}\text { Unions } \\
\text { recognised }\end{array}$ & $\begin{array}{c}\text { HR manager } \\
\text { Ops managers (2) } \\
\text { TU rep. }\end{array}$ \\
\hline & 3 & Retail & Private & $350-400$ & $\begin{array}{l}\text { No unions } \\
\text { Recognised } \\
\text {-low density }\end{array}$ & $\begin{array}{c}\text { HR manager } \\
\text { Ops. manager } \\
\text { Companion } \\
\text { Reg.TU Officer }\end{array}$ \\
\hline & 4 & $\begin{array}{c}\text { Retail/ } \\
\text { Manufacturing }\end{array}$ & Private & $300-350$ & $\begin{array}{l}\text { No unions } \\
\text { Recognised } \\
\text {-low density }\end{array}$ & $\begin{array}{l}\text { HR manager } \\
\text { Ops. manager; } \\
\text { Companion }\end{array}$ \\
\hline & 5 & $\begin{array}{c}\text { Local } \\
\text { authority }\end{array}$ & Public & Over 40,000 & $\begin{array}{l}\text { Unions } \\
\text { recognised }\end{array}$ & $\begin{array}{c}\text { HR Manager (2) } \\
\text { TU rep. } \\
\text { Ops. manager }\end{array}$ \\
\hline & 6 & $\begin{array}{l}\text { Transport } \\
\text { Service }\end{array}$ & Public & $750-1,000$ & $\begin{array}{l}\text { Unions } \\
\text { recognised }\end{array}$ & $\begin{array}{l}\text { HR manager } \\
\text { Ops. manager } \\
\text { TU rep. }\end{array}$ \\
\hline & 7 & Personal Care & Public & $100-150$ & $\begin{array}{l}\text { No unions } \\
\text { Recognised } \\
\text {-low density }\end{array}$ & $\begin{array}{l}\text { HR manager } \\
\text { Reg. TU Officer }\end{array}$ \\
\hline Wave & Organisation & Industry & Sector & Employment & $\begin{array}{c}\text { Employee } \\
\text { Representation }\end{array}$ & \\
\hline \multirow{5}{*}{2} & A & Health & Public & $2-3,000$ & $\begin{array}{l}\text { Unions } \\
\text { recognised- } \\
\text { high density }\end{array}$ & $\begin{array}{c}\text { Ops managers (6) } \\
\text { HR practitioners (5) } \\
\text { Mediation trainer (1) } \\
\text { TU reps (6) }\end{array}$ \\
\hline & B & Services & Private & $5-7,000$ & $\begin{array}{l}\text { Unions } \\
\text { recognised- } \\
\text { high density }\end{array}$ & $\begin{array}{c}\text { HR practitioner (17) } \\
\text { Ops managers (16) } \\
\text { TU reps (6) }\end{array}$ \\
\hline & $\mathrm{C}$ & $\begin{array}{c}\text { Public } \\
\text { administration }\end{array}$ & Public & $8-10,000$ & $\begin{array}{l}\text { Unions } \\
\text { recognised- } \\
\text { high density }\end{array}$ & $\begin{array}{c}\text { HR practitioner (3) } \\
\text { Ops managers (10) } \\
\text { TU reps (2) } \\
\text { Mediation co- } \\
\text { ordinator }\end{array}$ \\
\hline & $\mathrm{D}$ & Services & Private & Over 50,000 & $\begin{array}{c}\text { Non-unionised } \\
- \\
\text { active staff } \\
\text { association } \\
\end{array}$ & $\begin{array}{l}\text { Ops managers (17) } \\
\text { HR practitioner (10) } \\
\text { Employee reps (2) }\end{array}$ \\
\hline & $\mathrm{E}$ & $\begin{array}{l}\text { Social } \\
\text { services }\end{array}$ & $\begin{array}{l}\text { Non- } \\
\text { profit }\end{array}$ & $4-5,000$ & $\begin{array}{l}\text { Unions } \\
\text { recognised - } \\
\text { low density }\end{array}$ & $\begin{array}{l}\text { Ops managers (16) } \\
\text { HR practitioner (12) }\end{array}$ \\
\hline
\end{tabular}

